\title{
How convincing is the case for God? The Finnes Gud? television series offers you the chance to assess it! 1
}

\author{
Iain Morris \\ Executive Director and Producer \\ Kharis Productions, Hamilton, Scotland \\ iain@kharisproductions.com
}

There are times in life when one is conscious of a 'wake-up call'. I seem to encounter them quite regularly and they tend to impact my life and my priorities.

One memorable example was the first time I encountered Richard Dawkins on television. In a series on prime time on the UK's Channel 4, he presented a series called The Root of All Evil? While the Bible claims that the root of (all kinds of) evil is the love of money, Dawkins implied it was religion - Christianity included. According to Dawkins, the insistence on there being a God is Medieval - fit only for a time when we had a more primitive understanding of science. Can there be anything more damaging than substituting science with magic? Can there be anything more destructive of intelligence and civilisation than teaching innocent children that there is a creator God who intended to bring the universe into existence - especially since we can show it achieved that all by itself!

What amazed me about this Dawkins TV series is that it broke all the rules of balanced broadcasting. Interviews that had been conducted with Christian theologians and/or scientists, ended up in the trash bin.

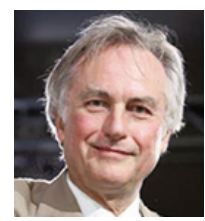

Richard Dawkins, arch opponent of religion.

Because of that indirect encounter, I went on to produce a TV series called The God Question. It is available with Norwegian subtitles as Finnes Gud? More in a moment.

Richard Dawkins has been a major catalyst in convincing wavering minds that belief in God involves being anti-intellectual and anti-science. In other words, to be a believer is to say farewell to your brain! Even though some claim that the New Atheism movement now has a diminished presence, it has a formidable continuing popular legacy. And Dawkins has a new audience in mind: children and young people. His latest book is for them - Outgrowing God.

So is there any response needed? Isn't it better that Christians ignore the issue and just go on living and preaching the Gospel? Then the problem might just go away! 


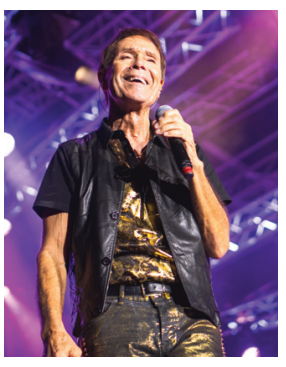

Sir Cliff Richard OBE Credit: Raph_PH, Creative Comm

Let me return to the subject of wake-up calls. On the evening before writing this article, I watched a TV interview with Cliff Richard. In it, there was reference to the fact that he is very open about his Christian faith, and has been since 1985, when he appeared at a Billy Graham meeting in Sheffield, England. In the course of discussing the problems that might have caused, a number of concerned friends appeared on screen confessing that they had been sure that such openness about Christian faith would cause Cliff's career to come to a sudden end. My wake-up call was that they should assume so.

Is being a Christian now really perceived as weird? Could it even be dangerous? Might it be a career killer? How far we have come from the point where our civilisation was known as Christendom! Yes, a response is needed. So very much needed! And the response we need is to evaluate the evidence as objectively as possible. Religious belief should not be based only on culture or historical tradition but on showing that belief is founded on good evidence. One might wish to claim that Christianity is the best explanation in the world about why we exist, but without being able to supply evidence it is harder to make the case. Evidence stands up if it survives being put to the test.

$* * *$

And that takes us to The God Question series: Finnes Gud? as it is known in Norway.

As a TV producer and director, programmes have become my favoured communication medium. What if we were to assemble on TV the world's most renowned believers alongside the world's most outspoken atheists? What if we took them on three crucially important journeys in which all on the journey exploded with wonder and then posed the question how all this can be explained? What would the result be? Would the finger of evidence point towards our existence emerging from an accumulation of

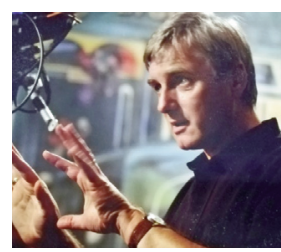

TV Director Iain Morris at work chance events in the cosmos and on earth or is the better explanation that we are the result of an intelligent mind, a creator? But where should we take our illustrious cast?

Programme 1, after setting out the ongoing conflict between the theist and atheist worldviews, blasts off into the cosmos. There our expert travellers tell the fascinating scientific story of the origins of the universe: every

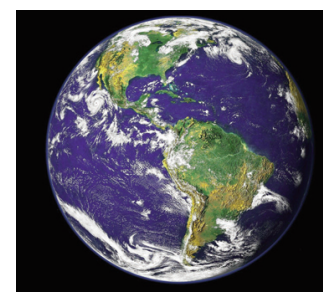
quark and atom that would ever exist was somehow represented in a dot you would not

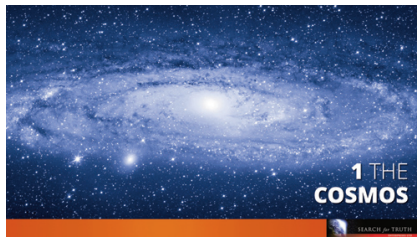

Programme 1: The Cosmos have been able to see! And then it grew, in what is termed the Big Bang. Of course the normal outcome of an explosion is chaos. But not so here.

In the first three minutes of the life of the newly born universe, 
elements crucial for its onward development began to form. Helium and hydrogen - fundamental to light and water and life - arrived! The split second timing (three minutes, not more not less) was vital to getting the balance right. And spread over billions of years the creative process continued. Out of gas and dust left over from the Big Bang, stars and planets began to form. In our solar system, $99.9 \%$ of the raw material was absorbed to form the sun. That left $1 \%$ for the formation of the planets including earth, from where we now look out, marvel and ask big questions about how and why.

Naturally, we look to science to reveal how but it cannot explain why. We must use our reasoning faculties for that. Was it all blind chance or is this real evidence for a mind behind the universe? How much faith does it take to believe in chance? Some argue that the force shaping the creativity of the universe is the laws of physics. But doesn't that beg the question: where did they come from? And there's more. For life to be sustained in the universe, finely tuned forces are required. The fine tuning in some cases is to at least 56 decimal places. Incredible! To believe in the creator in the face of such evidence is not to deploy magic; it is to accept the only reasonable and rational explanation we have! Of course, we must listen to the atheist reasoning on this too. Can the concept of 'multiverse' convince us that we really are just products of chance? That decision is for viewers to make.

Programme 2 brings us back to earth where the big question is: can the wonder of life itself - as well as the unique features of its host planet - be more convincingly explained as chance or a creator's intention? Atheists enter this fray in more confident mood. Has not Charles Darwin in his On the Origin of Species explained all we need to know about the development of life on earth

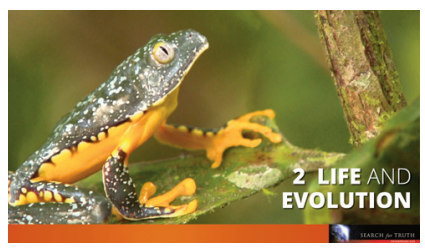

Programme 2: Life and Evolution through 'random mutation and natural selection'? One might argue that it takes substantial faith to accept that a mindless process can eventually arrive at something as sophisticated as the human mind! The issue here is not whether evolution is a 'true' account of the development of life on earth but whether such a system could work without a creator's involvement - even though we may be unclear about what that involvement precisely is.

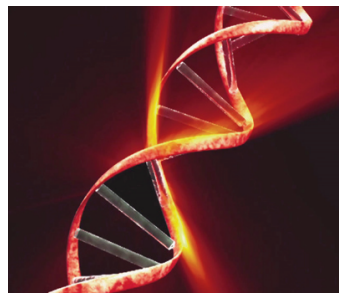

The mindless chance explanation is further challenged by the realisation that at the heart of life is the DNA code: 3 billion letters that combine in various ways to form the instruction book that builds living things. Within species those living things are essentially the same - otherwise community would not be possible, but the system also cleverly creates individuality. So we are, necessarily, the same but wonderfully individualistic too! Amazing!

$* * *$

And let's not forget that the mystery and the wonder of life itself is so far unexplained. So too is why planet earth should have so many life-encouraging properties - such as 
the phenomenon of water and a climate that protects and feeds life.

And so, the bank of evidence, to be weighed and assessed, builds.

$* * *$

Programme 3 takes us on the final journey - into the depths of the human mind and brain. It is the story of human consciousness. Here we truly are in the presence of instruments of wonder: the intricacies of the thought process, of language, of body co-ordination. But there is more. The mind and brain are capable of recognising beauty, of being creative and of problem solving and of

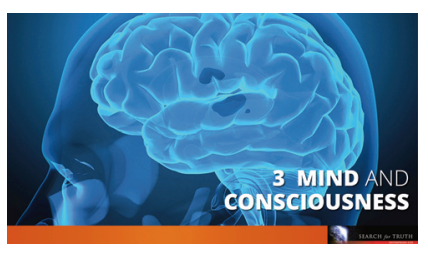

Programme 3: Mind and Consciousness making moral choices and distinctions between right and wrong. How can this be explained in purely evolutionary terms?

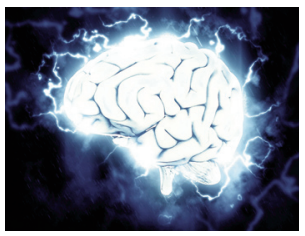

Programme 3: A human brain

Ultimately those same cerebral instruments, for most people across the world, sense a presence outside of themselves that we might call 'God'. Is this wishful thinking or might it be that humans are hard wired by their creator to make the ultimate connection? And if the connection is made, is there any evidence of impact? Personal testimonies supply some evidence to be pondered. By now we have gone beyond science, but to science we return, in order to investigate a world wide experiment taking place to test if human consciousness continues after the point of clinical brain death. The results are fascinating.

And so the jury is called once more to assess if there is a rational case to be made for a mind behind such sophisticated wonder.

$* * *$

Accompanying the series is a study guide that helps viewers absorb and remember the content of the programmes. Here they also receive summaries of The Case for Theism and The Case for Atheism as well as find a range of questions that help them to evaluate the evidence.

The question of God's existence is often decided (for believers and non-believers) on the basis of intuition, culture or peer group influence. Finnes Gud? offers an evidencebased opportunity to understand the issues.

Since its release, The God Question has been shown on scores of TV channels across the world with millions having had the opportunity to view it in their own language. NRK in Norway was the second European channel to acquire it, after SVT in Sweden. The series has been shown in universities and in schools, in churches and in homes. There are many reports of how it has strengthened belief and challenged scepticism.

For those who prefer a 'fast track' approach, a new version called The God Question for Starters has recently been produced. There are ten extracts

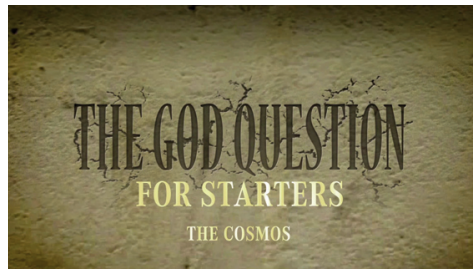


of 3-5 minutes for each of the three programmes, with an on-screen question at the conclusion of each extract. This is also available with Norwegian subtitles.

In Outgrowing God, Richard Dawkins argues that belief in a creator is a childish thing that should be naturally abandoned by thinking people. Thinking is integral to The God Question series. Perhaps he should 'think again'!

Especially now that The God Question series is

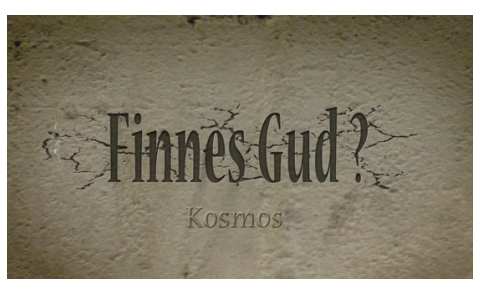
available with subtitles in Norwegian, take advantage! Assemble a group from your church to view and discuss; provide a copy for your local high school; use the series with your church youth group; gift a copy to friends or contacts who are sceptical about belief in God. The best way for them to decide is to consider the evidence.

1 For introduction, key resources, and access to the Finnes Gud? version with Norwegian subtitles, see https://finnesgud.no. The original version is introduced at http://www.thegodquestion.tv/. 


\section{Finnes Gud? Science, God and the search for truth}

Join a cast of experts debating evidence for God's existence as they:

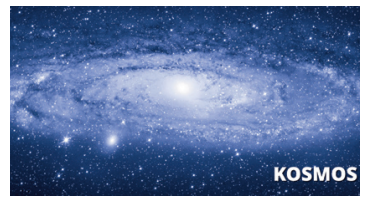

- journey into the cosmos

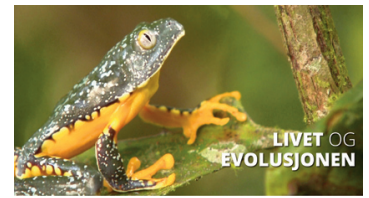

- explore the wonders of life

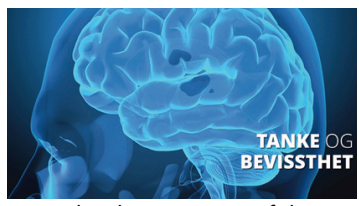

- probe the mysteries of the human mind and brain
"Superb programmes for all who want to understand why Christianity is a better and more convincing explanation of our existence than atheism." Professor John Lennox, The University of Oxford
"Every believer and non-believer should see this excellent series that addresses the most important questions of life."

Dr Greg Pritchard, Director European Leadership Forum

Order with Norwegian subtitles from www.finnesgud.no

\section{The God Question for Starters}

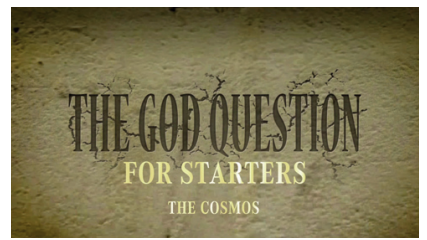

- Take the 'fast track' version of the Finnes Gud? series with ten short excerpts per programme

- Perfect for all who wish to take the Science and God question journey more quickly

- Ideal for younger teenage viewers and those in a hurry to learn

"A wonderful new resource to equip Christians to answer the questions people are asking."

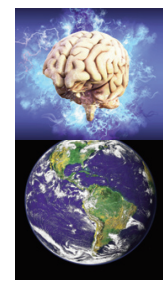
Rev Dr Fergus Macdonald, Former General Secretary, United Bible Societies.

"Nothing better for stimulating debate about the big issues in life."

Dr Liam Fraser, Campus Minister, The University of Edinburgh.

\section{Order with Norwegian subtitles from www.finnesgud.no}

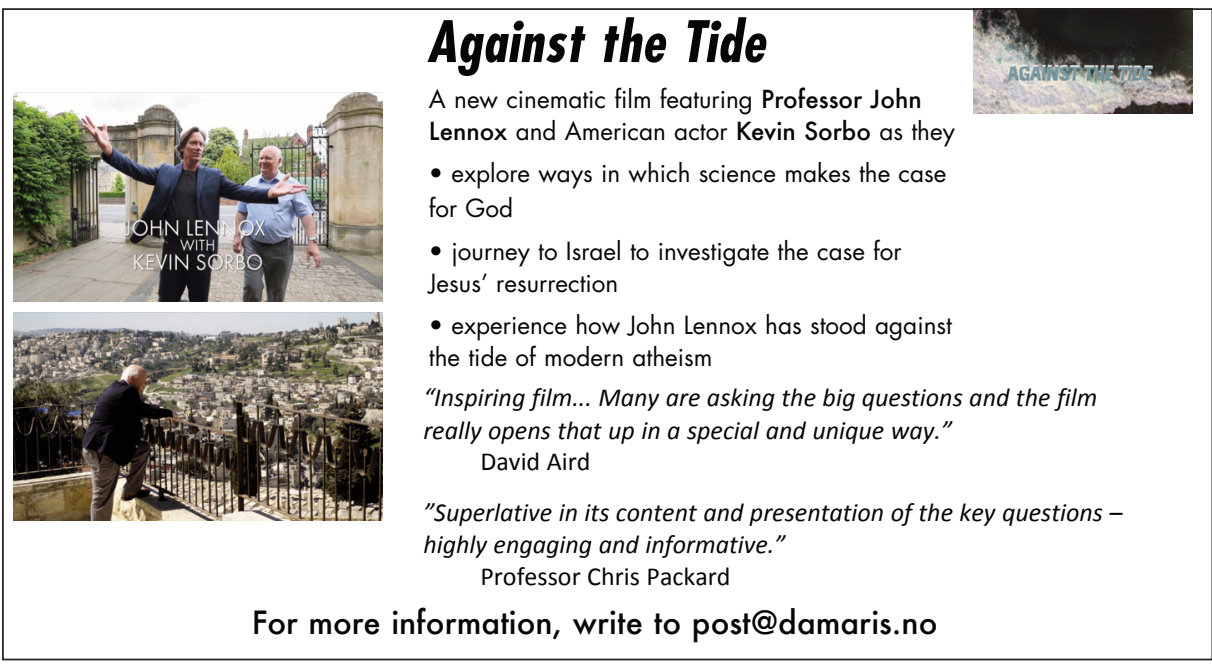




\section{Outgrowing God? A Beginner's Guide to Richard Dawkins and the God Debate \\ (Cascade Books, 2020)}

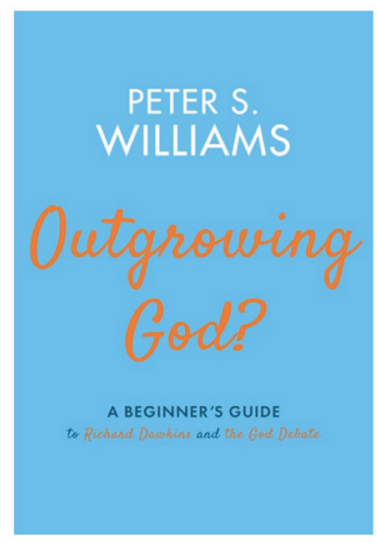

Outgrowing God? A Beginner's Guide to Richard Dawkins and the God Debate (Cascade, 2020) is a response to atheist Richard Dawkins' book Outgrowing God: A Beginner's Guide (2019). Join a cast of characters, with different perspectives, thinking through some of the biggest questions in life, as they discuss atheist Richard Dawkins' book Outgrowing God: A Beginner's Guide.

Written in the form of a dialogue between members of a student book club, Outgrowing God? A Beginner's Guide to Richard Dawkins and the God Debate encourages critical thinking about Professor Dawkins' arguments concerning God, Jesus, and the Bible.

'[a] delightful dialogue/critique of one influential atheist's philosophy...'

- Craig L. Blomberg, Distinguished Professor of New Testament, Denver Seminary

'Excellent work . . engaging, interesting and insightful.'

- Dr Lars Dable, Associate Professor in Systematic Theology and Christian Apologetics at NLA University College, Norway

'an important and insightful book... I highly recommend it.'

- J.P. Moreland, Distinguished Professor of Philosophy, Biola University

'provides many stimulating arguments on an introductory, easy-to-understand level... tackling decisive philosophical, theological, historical and scientific arguments, and providing many useful resources...'

- Martin Heide, Professor of Semitic Languages, Phillip University in Marburg, Germany

Review copies can be ordered from https://wipfandstock.com/outgrowing-god.html

Kindle or paperback from www.amazon.com

For more information and related resources, including video and audio materials, visit: www.peterswilliams.com/publications/books/outgrowing-god/ 